\title{
Review: Fitokimia genus Baccaurea spp.
}

\author{
Gunawan $^{1,2}$, Tatik Chikmawati ${ }^{3}$, Sobir ${ }^{4}$, Sulistijorini ${ }^{3}$ \\ ${ }^{1}$ Program Studi Biologi Tumbuhan, Sekolah Pascasarjana, Institut Pertanian Bogor, Bogor 16680 \\ ${ }^{2}$ Program Studi Biologi, Universitas Lambung Mangkurat, \\ Jl. A.Yani Km. 36 Banjarbaru Kalimantan Selatan \\ ${ }^{3}$ Departemen Biologi, Fakultas Matematika dan Ilmu Pengetahuan Alam, \\ Institut Pertanian Bogor, Bogor 16680 \\ ${ }^{4}$ Departemen Agronomi dan Hortikultura, Fakultas Pertanian, Institut Pertanian Bogor, Bogor 16680 \\ Email: ggunlam@gmail.com
}

\begin{abstract}
Abstrak
Genus BaccaureaLour. adalah salah satu anggota dari famili Phyllanthaceae, merupakan genus yang cukup besar dengan anggota mencapai 43 spesies. Pada pengobatan tradisional genus Baccaurea telah dimanfaatkan masyarakat untuk mengobati sembelit, pembengkakan pada mata, radang sendi, abses, sakit perut, memperlancar haid serta buang air kecil. Beberapa anggota genus Baccaureamemiliki potensi sebagai tumbuhan obat karena mengandung metabolit sekunder seperti alkaloid, flavonoid, karotenoid, antosianin, tanin, asam rosmarinik dan fenolik. Kandungan metabolit sekunder tersebut berpotensi sebagai antioksidan, antikanker, antimikroba, antidiabetes, antiinflamasi, antitripanosoma. B. ramiflora, B. lanceolata, B. macrocarpa, B. angulata, B. motleyana, B. brevipes, B. hookeri, B.recemosa, B. sapida, B. polyneura, B.parviflora dan B.dulcis adalah anggota genus Baccaurea yang berpotensi sebagai tumbuhan obat.
\end{abstract}

\section{Latar Belakang}

Tumbuhan telah memberikan banyak manfaat terhadap kehidupan manusia, yaitu sebagai sumber pangan dan sebagai bahan obat. Tumbuhan obat adalah tumbuhan yang mengandung bahan yang dapat digunakan untuk pengobatan (Sofowora 1982). Tumbuhan obat telah digunakan selama ratusan tahun sebagai sumber bahan obat dan mempunyai peran penting dalam menyembuhkan beberapa penyakit (Amin dan Nabi 2015). Sampai saat ini terdapat kurang lebih $60 \%$ tumbuhan yang telah digunakan sebagai tanaman obat (Harvey 2000). Obatobatan yang ada saat ini, merupakan hasil pengembangan dari tumbuhan dengan berbagai pendekatan bidang ilmu yaitu botani, etnobotani, fitokimia, biologi dan teknik pemisahan kimia (Amin dan Nabi 2015).

Tumbuhan dapatdigunakan pada beberapa pengobatan tradisional karena mempunyai beberapa kandungan bahan kimia aktif yang mempunyai efek farmakologi. Pada umumnya senyawa aktif tersebut tidak berperan dalam metabolisme primer, sehingga disebut metabolit sekunder (Liu et al.1998). Beberapa produk metabolit sekuder yang dapat digunakan sebagai bahan obat adalah flavanoid, alkaloid, polifenol, steroid, tannin (Smith 1976). Bahan kimia tersebut bagi tanaman berfungsi sebagai bahan yang penting untuk pertumbuhan dan pertahanan tumbuhan, sedangkan bagi manusia bahan kimia tersebut dapat dimanfaatkan sebagai sumber makanan dan bahan obat alami.Pada pengobatan tradisionalyang telah berlangsung ratusan tahun, masyarakat telah memanfaatkan senyawa metabolit sekunder dalam bentuk ramuan atau jamu, yang terdiri dari berbagai jenis tumbuhan.

Salah satu tumbuhan yang mempuyai khasiat obat adalah genus Baccaurea. Genus BaccaureaLour. Adalah salah satu anggota dari famili Phyllanthaceae, 
merupakan genus yang cukup besar dengan anggota mencapai 43 spesies yang tersebar dari India, Borneo, Sumatra, Jawa, Semenanjung Malaysia, Thailand, Filipina, sampai pulau Pasifik (Haegens 2000).Bagian tumbuhan yang sering digunakan untuk obat adalah bagian buah, daun, dan kulit batang. Genus Baccaurea pada umumnya dimanfaatkan buahnya sebagai buah segar dan kayu sebagai bahan bangunan. Pada pengobatan tradisional genus Baccaureadimanfaatkanmasyarakat untuk mengobati sembelit, pembengkakan pada mata, radang sendi, abses, sakit perut, memperlancar haid serta buang air kecil.

\section{GenusBaccaurea spp.}

Genus Baccaurea pertama kali dideskripsikan oleh Loureiro pada tahun 1790. Muller pada tahun 1866 mendeskripsikan marga Baccaurea dengan 31 jenis. Publikasi berikutnya oleh Backer dan Bakhuizen van der Brink (1963), Whitmore (1973), Smith (1978), Fernando (1979) dan Airy Shaw (1980, 1981) tidak merubah klasifikasi dari marga Baccaurea. Haegens (2000) kembali mendeskripsikan marga Baccaurea dengan 43 spesies. Berdasarkan sistem klasifikasi sebelumnya genus Baccaurea masuk ke dalam famili Euphorbiaceae, namun berdasarkan sistem klasifikasi APG II, berdasarkan bukti molekuler dan morfologi ovul dimasukkan ke dalam famili Phyllanthaceae (Seccoet al. 2012).

GenusBaccaureamerupakan genus yang cukup besar yang tersebar dari India, Borneo, Sumatra, Semenanjung Malaysia, Thailand, Filipina, sampai pulau Pasifik (Haegens 2000). Anggota genusBaccaurea banyak ditemukan tumbuh subur di hutan tropis dan dataran rendah, iklim mikro yang basah, lembab sampai kering dengan ketinggian 0-1300 di atas permukaan laut. Genus ini juga banyak ditemukan di sekitar aliran sungai, dengan jenis tanah berpasir atau tanah laterit (Lim 2012).

Baccaurea mempunyai habitus pohon, rasa buah asam sampai manis, bagian buah yang dimakan adalah bagian arill. Beberapa spesies yang dijual di pasar tradisional yaitu: B. motleyana (nama lokal: Rambai) di Semenanjung Malaysia, Sumatera, Jawa, Bali, dan Borneo; $B$. dulcis (nama lokal: Cupa) di Sumatera; B. ramiflora(Nama lokal: Latka (India, Cina), Kanaso (Burma)(Uji 1991; Van Valkenburg 1997). Beberapa spesies yang tidak umum dibudidayakan yaitu : B. angulata, B. bracteata, B. edulis, $B$. macrocarpa, B. lanceolata, B. polyneura, B. pubera, B. racemosa, dan B. reticulata. Selain dimanfaatkan buahnya Baccaurea juga dimanfaatkan kayunya sebagai bahan bangunan: B. bracteata, B. dulcis, B. javanica, B. lanceolata, B. macrocarpa, B. macrophylla, B. minor, B. motleyana, B. nanihua, B. polyneura, B. racemosa, B. ramiflora, $B$. parviflora,dan B. reticulata (Salma 1998).

BuahBaccaureadianggap memiliki nilai ekonomi yang rendah,karena buahnya kurang diminati dan hanya beberapa jenis saja yang diperjualbelikan di pasar tradisional. Namun, buahnya memiliki nilai ekologis yang penting, karena buah yang dihasilkan masuk ke dalam jaring-jaring makanan, dan merupakan sumber makanan oleh banyak spesies burung,hewan pengerat, rusa, dan monyet, termasuk orang utan (Rijksen 1978).

\section{Diversitas Fitokimia pada Baccaurea spp.}

Genus Baccaurea merupakan salah satu takson yang memiliki potensi sebagai tumbuhan obat. Penelitian sebelumnya melaporkan bahwa beberapa genusBaccaurea memiliki potensi sebagai tumbuhan obat karena mengandung 
metabolit sekunder. Anggota genus Baccaurea yang diketahui mempunyai kandungan metabolit sekunder dan berpotensi untuk digunakan sebagai tumbuhan obat adalah $B$. ramiflora, $B$. lanceolata, B. macrocarpa, B. angulata, B. motleyana, B. brevipes, B. sapida, B. hookeri, B.racemosa, B.parviflora,B.dulcis dan B. polyneura.

Baccaurea ramifloratersebar dari Nepal sampai Sikkim, Darjeeling, Pradesh, Tripura, Assam, Bhutan, Burma, Semenanjung Malaysia, Tibet dan pulau Andaman (Goyal et al. 2013).Buah $B$. ramiflora mengandung flavonoid, flavonol, proanthocianidin, vitamin $C$, protein dan besi yang tinggi. Jenis fenol 6'- O-vanilloylisotachioside \& 6'- Ovanilloyltachioside ditemukan

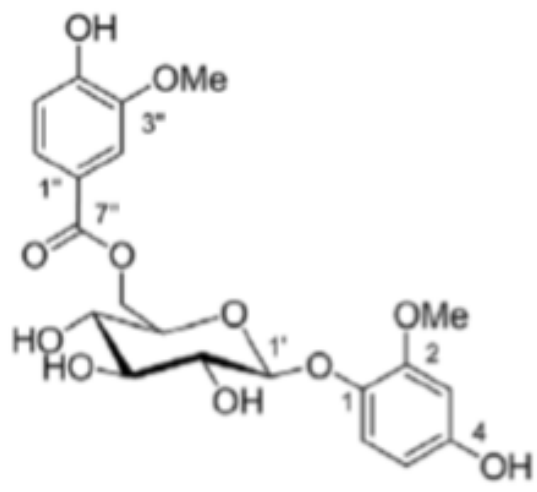

1

Gambar 1. Senyawa fenol pada daun $B$. Ovanilloyltachioside (Yang et al. 2007)

Baccaurea ramifloradi India selain dimakan dalam keadaan segar juga dibuat minuman dengan cara fermentasi. Penelitian Goyal et al. (2013) yang membandingkan kandungan flavonoid, flavonol dan aktifitas anti oksidan pada buah segar dan minuman fermentasi menunjukkan bahwa buah segar memiliki kandungan flavaniods, flavonol dan aktifitas antioksidan yang lebih tinggi dari pada B. ramiflora yang difermentasi dibagian daun (Gambar 1.), sedangkan 4'-O- (6- O-vanilloyl) -beta-D-glucopyranosyl tachiosideD, 6'-O-vanilloylpicraquassioside $\mathrm{D}$ dan 6'-O-vanilloylicariside B terdapat pada batang B. ramiflora(Lin et al. 2003; Yang et al. 2007). Selain itu, ekstral metanol daun $B$. ramiflora juga mengandung asam Rosmarinic yang berpotensi sebagai anti inflamasi (Usha et al. 2014). Jus buahnya digunakan untuk mengatasi sembelit. Bagian buah yang lain digunakan untuk mengobati radang sendi dan luka-luka (Goyal et al. 2013).Ekstrak metanol buah $B$. ramiflora menunjukkan aktivitas antioksidan yang kuat dengan nilai IC50 49,78 ug / ml fraksi larut dan petroleum eter menunjukkan aktivitas antioksidan yang baik dengan nilai IC50 75,31 ug / ml (Amin dan Nabi 2015).

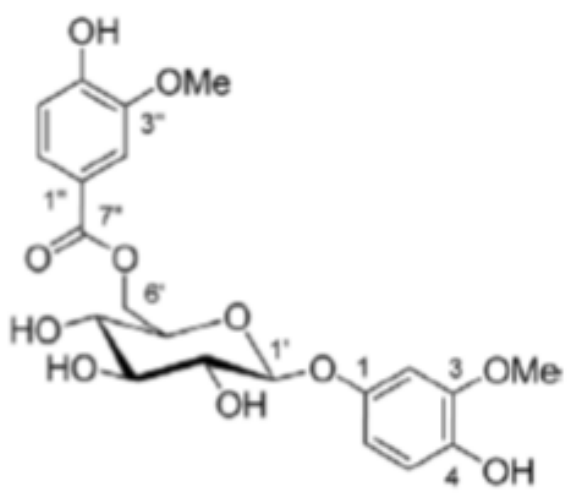

2

ramiflora.1.6'- O-vanilloylisotachioside, 2.6'-

Ullah et al. (2012) melaporkan bahwa daun $B$. ramifloramempunyai aktifitas hipoglikemik, hipolipidemik dan antioksidan. Hal ini menunjukkan bahwa daun $B$. ramiflora dapat digunakan untuk pengobatan penyakit diabetes millitus. Mekanisme hipoglikemik dan hipolipidemik dari daun B. ramiflora belum diketahui. Namun hal ini diduga berkaitan dengan aktifitas antioksidan, adanya flavonoid, tanin, terpen dan steroid. 
Baccaurea lanceolataatau dikenal dengan nama langsat hutan, jenis ini dapat ditemukan di Thailand, Semenanjung Malaysia, Sumatra, Borneo (Serawak, Brunei, Sabah, Kalimantan SelatanTimur) dan Phillipina (Lim 2012). Dalam pengobatan tradisional tumbuhan ini digunakan untuk mengobati sakit perut, mengatasi pembekakan dan mengobati mabuk karena alkohol (Lim 2012). Voon dan Kueh (1999) melaporkan kandungan buah $B$. Lanceolata terdiri dari air $92.4 \%$, energi $18 \mathrm{kcal}$, protein $0.2 \%$, fat $0.2 \%$, karbohidrat $3.7 \%$, kadar abu $0.8 \%$, P 6 mg, K 126 mg, Ca 35 mg, Mg 11 mg, Fe 0.3 mg, Mn 2 ppm, Cu 1.5 ppm, Zn 6.3 pm, dan vitamin C $0.6 \mathrm{mg}$. Buah $B$. Lanceolata juga mengandung fenol, flavonoid, antosianin, dan karotenoid (Bakar et al. 2014).

Kandungan fitokimia $B$. lanceolata terdapat pada pericarp dan daging buah, dengan kandungan tertinggi terdapat pada daging buahnya. Uji aktifitas antioksidan dengan tiga metode $(\mathrm{DPPH}$, ABTS, dan FRAP) pada bagian pericarp, daging buah dan biji menunjukkan aktifitas antioksidan yang tinggi, dengan aktifitas tertinggi terdapat pada bagian daging buah (Bakar et al. 2014).

Baccaurea macrocarpa atau dikenal dengan nama jantikan, kapul dan tampoi, dapat ditemukan Semenanjung Malaysia, Sumatra, Borneo (Serawak, Brunei, Sabah Kalimantan Tengah-Selatan dan Timur) (Lim 2012). Batang tumbuhan ini banyak digunakan sebagai bahan bangunan, buahnya dimakan segar karena rasanya yang manis (Haegens 2000). Spesies ini dilaporkan mengandung senyawa metabolit sekunder, diantaranya adalah saponin, flavonoid, alkaloid, fenol, antosianin, dan karotenoid (Tirtana et al. 2013; Bakar et al. 2014).

Antosianin merupakan senyawa turunan struktur aromatik tunggal yang bertanggung jawab memberikan warna pada buah, sayur dan tanaman hias (Gambar 2.) (Harbone 2005). Senyawa antosianin merupakan metabolit sekunder dari kelompok flavonoid, jenis yang banyak ditemukan adalah peonidin, sianidin, malvidin, petunidin, pelargordin, dan delfinidin (Karnjanawipagul et al. 2010).Antosianin bersifat amfoter, yaitu mampu untuk bereaksi dengan asam maupun basa (Man 1997).

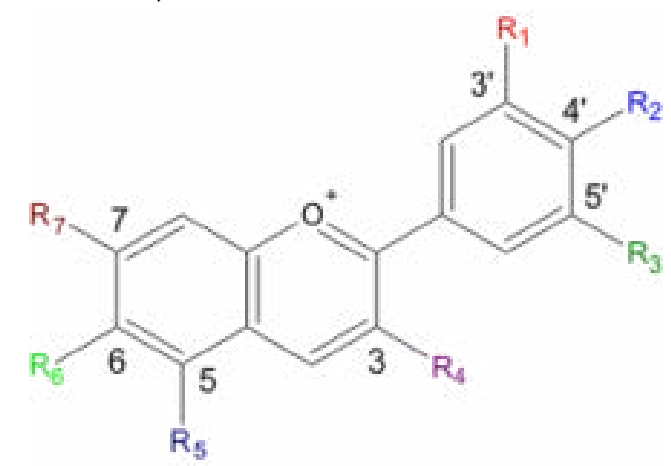

Gambar 2. Struktur Antosianin

Antosianin memiliki ikatan rangkap terkonjugasi yang panjang, sehingga mampu menyerap cahaya pada rentang cahaya tampak, hal ini yang memberikan pengaruh warna pada buah dan sayuran. Antosianin juga berperan dalam menghambat proses aterogenesis dengan cara mengoksidasi lemak jahat dalam tubuh. Selain itu, antosianin juga mampu mencegah obesitas dan diabetes, meningkatkan kemampuan memori otak dan mencegah penyakit neurologis (Harborne 1987).

Biji buah B. macrocarpa juga mengandung nutrisi seperti serat $2.2 \%$, lemak $1.1 \%$, karbohidrat $34.6 \%$, protein $1.5 \%$, air $61.9 \%$ dan vitamin C $1.5 \%$ (Tirtana et al. 2013).B. macrocarpa mempunyai kandungan fitokimia tertinggi pada bagian pericarp. Uji aktifitas antioksidan dengan tiga metode (DPPH, ABTS, dan FRAP) pada bagian pericarp, daging buah dan biji menunjukkan aktifitas 
antioksidan yang tinggi, dengan aktifitas tertinggi terdapat pada bagian pericarp (Bakar et al. 2014).

Baccaurea angulata atau dikenal dengan nama belimbing merah, belimbing darah, tampoi hutan dan asam ketiak merupakan salah satu anggota genus Baccaureayang hanya terdapat di Borneo. Buah belimbing merah mengandung protein, karbohidrat, fiber, mineral dan vitamin C (Voon dan Kueh 1999).Beberapa penelitian telah mengungkapkan bahwa buah belimbing merah mengandung senyawa fenol, flavonoid, karotin dan aktifitas menghambat lipid peroksidase. Bagian buah yang paling banyak mengandung senyawa metabolit sekunder adalah bagian kulit buah (Ahmed et al. 2014). Norazlanshah et al. (2015) juga mengungkapkan bahwa belimbing merah juga mengandung vitamin A pada keseluruhan buah dan daging buah, vitamin $C$ pada bagian seluruh buah, kulit buah dan daging buah, dan vitamin E yang hanya terdapat pada kulit. Belimbing merah juga mengandung senyawa antosianin dan mempunyai aktifitas antioksidan yang tinggi pada kulitnya. Mikail et al. (2015) juga menyatakan bahwa jus belimbing merah dapat menghambat aktifitas lipid peroksidase dan menginduksi aktifitas enzim antioksidan.

Jus belimbing merah juga dapat digunakan untuk mencegah aterosklerosis,hal ini disebabkan aktifitas antioksidan belimbing merah dapat menghambat biomarker inflamasi dan mengurangi plak aterosklerosis dan stres oksidatif (Mikail et al. 2014). Penelitian lain yang dilakukan oleh Adam dan Bahar (2015), dengan melihat aktifitas protein MMP-13 pada sel kanker kulit manusia yang diberi perlakuan dengan ekstrak buah belimbing merah melaporkan bahwa ekstrak belimbing merah mempunyai efek regulatif pada aktifitas protein MMP13. Oleh karena itu, belimbing merah juga berpotensi sebagai sumber bahan alami untuk pengobatan kanker.

Ekstrak kulit buah belimbing merah juga mempunyai aktivitas antimikroba (Momand 2014). Hal ini ditunjukkan dengan efek penghambatan pada mikroba patogen yaitu Streptococcus pneumonia, Staphylococcus epidermidis, Klebsiella pneumonia dan Pseudomonas aeruginosa. Efek penghambatan tertinggi terjadi pada Streptococcus pneumonia, ekstraksi yang paling kuat memberikan efek penghambatan adalah ekstrak yang menggunakan pelarut etanol.

Baccaurea motleyanaatau dikenal dengan rambai, dapat ditemukan di Thailand, Semenanjung Malaysia, Sumatra, Jawa, Borneo (Serawak, Brunei, Sabah, Kalimantan Timur-Selatan-Barat) dan Moluccas (Lim 2012). B. motleyanatelah lama digunakan sebagai obat tradisional, batang bagian dalam digunakan untuk mengobati peradangan pada mata, bagian kulit juga dipakai sebagai bahan obat pelindung (Lim 2012). Ekstrak etanol, petroleum eter dan kloroform dari kulit buah $B$. motleyana menunjukkan aktifitas antibakteri Staphylococcus aureus, Bacillus cereus, Bacillus subtilis, Proteus vulgaris dan Escherichia coli (Suhaila et al. 1994). Buah rambai mengandung metil 2-hidroksi3-methylbutanoate, metil 2-hidroksi-3methylpentanoate dan metil 2-hidroksi4-methylpentanoate (Wong et al. 1994). Kandungan fenol buah B. motleyana pada kondisi muda, dewasa, matang berturut $97.23 \mathrm{mg} / 100 \mathrm{~g}, 63.90 \mathrm{mg} / 100 \mathrm{~g}$, dan 79.57 $\mathrm{mg} / 100 \mathrm{~g}$ (Mokhtar 2014). Penelitian terakhir yang dilakukan oleh Fitri et al. (2016) juga mengungkapkan bahwa buah B. motleyana mengandung fenol dan flavonol serta memiliki aktifitas lipid peroksidasi. 
Spesies Baccaurea racemosa dikenal dengan nama menteng, tumbuhan ini dapat dijumpai di Thailand, Semenanjung Malaysia, Sumatra, Jawa, Pulau Lesser Sunda, Borneo, Celebes dan Muluccas.Buah B.racemosa mengandung protein, karbohidrat, vitamin C dan kalsium (Ca) (Rohyani 2015). Ekstrak metanol B.racemosamempunyai aktifitas antioksidan sebesar 91,23 $\pm 0,02$ $\%$, yang termasuk dalam kategori tinggi(Wulansari dan Choirul 2011) dan kandungan fenolyang cukup tinggi (Sulaiman dan Ooi 2014).

Aktifitasantioksidandalamtumbuhan dipengaruhi oleh kandungan senyawa yang terdapat dalam tumbuhan tersebut. Salah satu metabolit sekunder yang telah diketahui memiliki aktivitasantioksidan adalah flavonoid yang termasukkedalam kelompok senyawa fenolik alam (Chairulet al. 2003).Selain flavonoid, senyawa polifenol juga berperan sebagai antioksidan alami (Rice-Evans et al.1996).

Ekstrak dan fraksi metanol kulit batang Ceria (Baccaurea hookeri) mengandung alkaloid, flavanoid, polifenol dan steroid. Uji aktivitas antioksidan dari ekstrak dan fraksi menunjukan nilai IC50 ekstrak metanol sebesar 56,47 $\mu \mathrm{g} / \mathrm{ml}$, fraksi n-heksan sebesar $68,07 \mu \mathrm{g} / \mathrm{ml}$, fraksi kloroform sebesar $82,68 \mu \mathrm{g} / \mathrm{ml}$, fraksi etil asetat sebesar $59,57 \mu \mathrm{g} / \mathrm{ml}$ dan fraksi metanol sebesar 29,88 $\mu \mathrm{g} / \mathrm{ml}$ (Panjaitan 2014). Sementara itu, hasil penelitian pada kulit batang $B$. hookeri mengungkapkan bahwa aktivitas antioksidan fraksi metanol hasil pemisahan dengan metode kromatografi vakum cair memiliki kemampuan menghambat radikal DPPH dengan nilai IC50 sebesar 9,265 $\mu \mathrm{g} / \mathrm{mL}$ 2(Maro et al. 2015). Fraksi metanol hasil pemisahan dengan metode kromatografi vakum cair mengandung senyawa golongan polifenol dan terpenoid. Polifenol merupakan golongan senyawa flavonoid terutama katekin dan epikatekin yang berperan sebagai antioksidan (Osakabe et al. 1998).

Spesies Baccaurea sapida adalah salah anggota genus Baccaurea yang buahnya dapat dimakan segar dan digunakan dalam pengobatan tradisional untuk artritis dan abses (Lin et al. 2003).Spesies ini mempunyai kandungan fenolik, flavonoid dan flavonol (Seal 2012) sehingga memiliki aktifitas antioksidan yang tinggi (Singh 2014). Buah B. sapida mengandung vitamin $C$, akarnya berfungsi sebagai antipiretik, dan pada bagian daunnya berfungsi sebagaisebagai antifungi (Wetwitayaklung 2012).

Baccaureaparvifloramerupakan salah satu anggota genus Baccaurea yang juga memiliki aktifitas farmakologi. Mohmodet al. (2015) melaporkan bahwa buah B.parviflora mempunyai kandungan antitripanosoma, dan berpotensi sebagai salah satu tumbuhan yang dapat digunakan untuk sumber bahan obat tripanosoma yang disebabkan oleh protozoa parasit Trypanosoma brucei. Komponen fitokimia dari tumbuhan yang mempunyai aktifitas anti tripanosoma adalah alkaloid, phenolik, quinon dan terpen (Hoet et al. 2004).

B. polyneura juga memiliki aktifitas farmakologi, Sulaiman dan Ooi (2014) mengungkapkan bahwa $B$. polyneura memiliki kandungan fenol dan vitamin $C$, serta memiliki aktiftas antioksidan. Selain itu, buah B. polyneura juga mengandung karotenoid (Khoo et al. 2008). Karotenoid adalah suatu pigmen warna yang menyebabkan warna orange merah, kuning dan hijau pada buah dan sayuran (Burn et al. 2003; Hughes 2001). Manfaat karotenoid diantaranya adalah sebagai prekursor vitamin $\mathrm{A}$, antioksidan dan meningkatkan daya tahan tubuh (Arabet al.2001; Zebet al. 2004, Yan, 1998). 
B.dulcisatau dikenal dengan nama kapul dapat ditemukan di Sumatra, Jawa, Borneo (Sabah, Kalimantan TengahSelatan-Timur), juga dimanfaatkan dalam pengobatan tradisional yaitu sebagai obat penyakit kulit dan antiinflamasi pada mata (Lim 2012). SpesiesB.brevipes juga digunakan dalam pengobatan tradisional, yaitu sebagai pengatur menstruasi dan memperlancar buang air kecil (Ali 2010). Namun demikian, belum ada informasi ilmiah yang mengungkapkan kandungan farmakologi dari kedua spesies tersebut.

\section{Senyawa Metabolit Sekunder Utama dalam Genus Baccaurea spp.}

Senyawa metabolit sekunder yang terdapat dalam genus Baccaurea dapat dikelompokkan menjadi 3 golongan, yaitu alkaloid, flavonoid dan fenolik.

\section{Alkaloid}

Alkaloid adalah golongan senyawa organik yang paling banyak terdapat di alam dan tersebar di hampir semua jenis tumbuhan. Senyawa alkaloid mengandung nitrogen dan bersifat basa serta memiliki aktifitas farmakologis (Lumbanraja 2009).Contoh struktur salah satu jenis senyawa alkaloid disajikan pada Gambar 3.

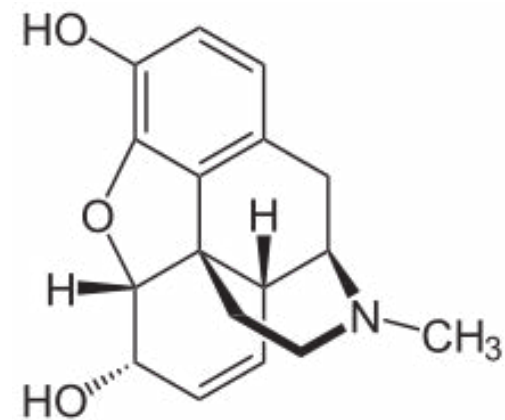

Gambar 3. Contoh struktur senyawa alkaloid (morfin)

Senyawa alkaloid berfungsi sebagai racun untuk melindungi tumbuhan dari herbivora (hama dan penyakit), dan sebagai basa mineral untuk menjaga keseimbangan ion.Senyawa alkaloid banyak digunakan dalam pengobatan, hal ini disebabkan karena senyawa alkaloid dapat berfungsi sebagai antioksidan(Harborne dan Baxter 1999), memacu sistem saraf, menaikkan atau menurunkan tekanan darah dan melawan infeksi mikrobia (Solomon 1980; Carey 2006). Alkaloid merupakan senyawa dengan jumlah paling besar, sehingga dapat digolongkan dengan beberapa cara, yaitu berdasarkan jenis cincin heterosiklik nitrogen, berdasarkan jenis tumbuhan asal alkaloid, dan berdasarkan asal-usul biogenetik. Senyawa alkaloid tidak mempunyai tatanama sistematik, sehingga suatu alkaloid diberinama dengan nama trivial, misalnya morfin, kuinin dan strikhinin.

\section{Flavonoid}

Flavonoid merupakan kelompok senyawa metabolit sekunder yang paling banyak ditemukan dalam jaringan tumbuhan, dalam bentuk struktur dan fungsi yang berbeda (Macheix et al. 1990). Senyawa flavonoid dalam tumbuhan terbentuk melalui jalur sikimat dan phenilpropanoid (Harbone 1989). Senyawa flavonoid juga merupakan kelompok senyawa phenolik dengan rumus kimia $\mathrm{C}_{6}-\mathrm{C}_{3}-\mathrm{C}_{6}$. Kerangka flavonoid terdiri atas satu cincin aromatik A, satu cincin aromatik B, dan satu cincin heterosiklik yang mengandung oksigen (Gambar 4), bentuk teroksidasi cincin ini dijadikan dasar pembagian flavonoid ke dalam sub-sub kelompoknya. Terdapat beberapa kolompok senyawa flavonoid, diantaranya adalah flavone, flavonone, isoflavone, flavanol, flavanon, anthocyanin, and chalchone (Porter 1994; Ferreira dan Bekker 1996; Ferreira et al. 1999a,b). Sejauh ini telah teridentifikasi kurang lebih 6467 
komponen flavonoids, danjumlahiniakan terus meningkat seiring ditemukannya jenis-jenis komponen flavonoid yang baru (Harborne dan Baxter 1999). Komponenkomponen tersebut mempunyai peran penting dalam menentukan warna, bau, rasa dan kualitas nutrisi makanan (Macheix et al. 1990). Senyawa flavonoid secara umum dalam bentuk monomer, namun ada juga yang berbetuk dimer, trimer, tetramer dan polimer (Perruchon 2004).<smiles>O=c1c(O)c(-c2ccc(O)c(O)c2)oc2cc(O)cc(O)c12</smiles>

Gambar 4. Struktur dasar flavonoid

Kelompok senyawa flavonoid berdasarkan strukturnya yaitu: Flavon, Flavonol, Flavanon, Flavononol, Isoflavon, dan Flavan-3-ol (Kumar dan Pandey 2013)(Gambar 5).<smiles>O=c1cc(-c2ccccc2)oc2ccccc12</smiles>

Flavon<smiles>O=C1c2ccccc2O[C@H](c2ccccc2)[C@@H]1O</smiles>

Flavononol<smiles>O=c1c(O)c(-c2ccccc2)oc2ccccc12</smiles>

Flavonol<smiles>O=c1c(-c2ccccc2)coc2ccccc12</smiles>

Isoflavon<smiles>O=C1C[C@H](c2ccccc2)Oc2ccccc21</smiles>

Flavonon<smiles>OC1Cc2ccccc2O[C@@H]1c1ccccc1</smiles>

Flavan-3-ol

Gambar 5. Kelompok flavonoid berdasarkan strukturnya

Beberapa penelitian menunjukkan bahwa komponen nutrisi tumbuhan yang mempunyai peran sebagai agen protektif terhadap penyakit tertentu, mempunyai sifat antioksidatif (Deshpande et al., 1985). Senyawa flavonoid dapat berperan sebagai antioksidan dengan cara mendonasikan atom hidrogennya atau melalui kemampuannya mengkelat logam, berada dalam bentuk glukosida (mengandung rantai samping glukosa) atau dalam bentuk bebas yang disebut aglikon (Cuppett et al.1954).

Senyawa flavonoid seperti quercetin, kaempferol, myricetin, apigenin, luteolin, vitexin dan isovitexin memiliki aktifitas antioksidan, antiinflamasi,antialergi, antivirus dan juga antikanker. Selain itu, kelompok flavonoid tersebut dapat melindungi dari kerusakan hati dan katarak ( Tapas et al. 2008). 


\section{Fenolik}

Senyawa fenolik merupakan senyawa metabolit sekunder yang terdapat pada tumbuhan dengan cincin aromatik dengan satu atau lebih gugus hidroksi $\left(\mathrm{OH}^{-}\right)$dan gugus-gugus lainnya (Gambar 6). Senyawa fenol disintasis melalui jalur sikimat dan fenilpropanoid (Dixon dan Paiva 1995).Berdasarkan jumlah sub unit fenol, senyawa fenolik dibagi dua yaitu fenol sederhana dan polifenol. Kelompok fenol sederhana juga disebut dengan asam fenolik atau fenol dengan gugus karboksil yang mempunyai fungsi spesifik, sedangkan polifenol adalah kelompok yang memiliki cincin fenol lebih dari dua (Harbone 1985).

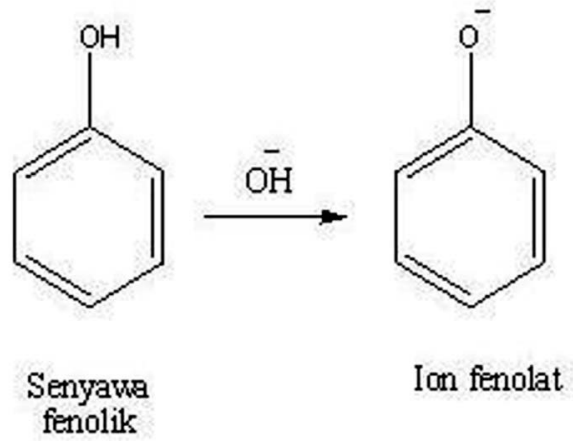

Gambar 6. Struktur senyawa fenolik

Senyawa fenolik mempunyai fungsi biokimia yang luas diantaranya sebagai antioksidan, antimutagenik, dan antikarsinogenik, selain itu juga berperan dan mempengaruhi ekspresi gen (Nakamuraet al. 2003). Kemampuan senyawa fenolik sebagai antioksidandisebabkan kemampuannya dalam mengkelat logam.Senyawa fenolik memiliki kelompok hidroksil dan karboksil, mampu mengikat logam terutama besi dan tembaga (Jung et al. 2003). Kemampuan senyawa tersebut dalam mengkelat logam kemungkinan terkait dengan kemampuan nukleofilic yang tinggi dari cincin aromatik (Morgan et al.1997)

\section{Penelitian ke depan}

Indonesia adalah negara tropis dengan keanekaragaman tumbuhan yang tinggi. Beberapa tumbuhan yang ada telah dimanfaatkan sebagai sumber pangan dan obat obatan. Namun demikian, banyak potensi tumbuhan obat yang belum diungkapkan secara ilmiah. Genus Baccaurea merupakan kelompok tumbuhan buah-buhan yang mempunyai potensi sebagai tumbuhan obat, karena beberapa anggotanya megandung senyawa metabolit sekunder dan telah digunakan dalam pengobatan tradisional.

Beberapa anggota genus Baccaurea selama ini dianggap buah yang kurang memiliki nilai ekonomi, namun beberapa penelitian terkait aktifitas fitokimia menunjukkan bahwa genus Baccaurea memiliki potensi sebagai sumber tumbuhan obat yang potensial. Namun demikian, konversi hutan dan berkurangnya luasan hutan yang selama ini terjadi, telah menyebabkan jumlah spesies Baccaurea telah berkurang dan bahkan tidak ditemukan lagi. $B$. annamensisadalah salah satu spesies yang tidak ditemukan lagi, spesies tersebut ditemukan terkahir pada tahun 1921 (Haegens 2000).

Penelitian terkait dengan inventarisasi, koleksi, karakterisasi dan evaluasi tanaman yang sudah ada sangat diperlukan untuk mencegah erosi genetik (Suryani dan Nurmansyah 2009). Selain itu, penelitian tentang komponen fitokimia dari genus Baccaurea perlu dilakukan untuk mengungkapkan manfaatnya sebagai tumbuhan obat, sebagai salah satu upaya konservasi plasma nutfah .

\section{Kesimpulan}

Genus Baccaureatelah digunakan masyarakat sebagai tumbuhan obat untuk mengobati sembelit, pembengkakan 
pada mata, radang sendi, abses, sakit perut, memperlancar haid serta buang air kecil. Kandungan metabolit sekunder yang terdapat pada beberapa anggota genus Baccaurea adalah alkaloid, flavonoid, karotenoid, antosianin, tanin, asam rosmarinik dan fenolik. Kandungan metabolit sekunder tersebut berpotensi sebagai antioksidan, antikanker, antiinflamasi, antimikroba, antidiabetes dan antitripanosoma. Meskipun memiliki potensi yang besar sabagai tumbuhan namun adanya konversi lahan dan berkurangnya luasan hutan yang terjadi dengan cepat, sangatmengancam kelestarian genus Baccaurea. Oleh karena itu, penelitian dankegiatan lebih lanjut terkait inventarisasi, konservasi, karakterisasi dan isolasi kandungan fitokimia Baccaurea perlu untuk dilakukan.

\section{Daftar Pustaka}

Airy Shaw, H.K. 1980. The Euphorbiaceae of New Guinea. Kew Bull. Add. Ser. 8: 34-37.

Airy Shaw, H.K. 1981. The Euphorbiaceae of Sumatra. Kew Bull. 36: 258-267.

Adam M, Bahar MS. 2015. Expression of Matrix Metalloproteinase-13 in Human Skin Melanoma Cancer Treated by Baccaurea angulata in vitro.Journal of Basic and Applied Research 1 (1): 21-28

Ahmed IA, Mikail MA, Ibrahim M, Hazali N, Rasad MSBA, Gani RA, Wahab RA, Arief SJ, Yahya MNA. 2014. Antioxidant actovity and phenolic profile of various morphological parts of underutilized Baccaurea angulata fruit. Food Chemistry.

Ali M. 2010. Medicinal Plant Diversity and Vegetation Analysis of Logged over Hill Forest of Tekai Tembeling Forest Reserve, Jerantut, Pahang. Journal of Agricultural Science. 2 (3)
Amin R, Nabi MN. 2015. Evaluation of cytotoxic and antioxidant activity of different fractions of methanolic extract of Baccaurea ramiflora (Lour.) fruits. International Current Pharmaceutical Journal. 4(6): 386-389

Arab L, Steck-Scott S, Bowen P. 2001. Partisipation of Lycopen and Betacarotene in Carcinogenesis:Defenders, Aggresors, or Passive Bystanders?. Epidemiologic Reviews. 23(2) :221229

Bakar MFA, Ahmad NE, Karim FA, Saib S. 2014. Phytochemicals and Antioxidative Properties of Borneo Indigenous Liposu (Baccaurea lanceolata) and Tampoi (Baccaurea macrocarpa) Fruits. Antioxidants 3: 516-525

Basso LA, Silva LH, Neto AG, Azevedo Jr WF, de Moreira IS,Palma MS, Calixto JB, Astolfi-Filho $S$, dos Santos RR, Soares MB, Santos DS. 2005. The use of biodiversity as source of new chemical entities against defined molecular targets for treatment of malaria,tuberculosis, and T-cell mediated diseases; A Review. Mem Inst Oswaldo Cruz 100: 475506.

Backer CA, \& Bakhuizen van den Brink RC. 1963. Euphorbiaceae. Flora of Java 1: 453-455.

Burns J, Fraser PD, Bramley PM. 2003. Identification and quantification of carotenoids, tocopherols and chlorophylls in commonly consumed fruits and vegetables. Phytochem 62:939-947 doi:10.1016/ S0031-9422(02)00710-02.

Carey, Francis A., 2006. Organic Chemistry, 6th ed., New York: McGraw Hill, 954. 
Cuppett, S., M. Schrepf and C. Hall III. (1954). Natural Antioxidant - Are They Reality. Dalam Foreidoon Shahidi: Natural Antioxidants, Chemistry, Health Effect and Applications, AOCS Press, Champaign, Illinois: 12-24

Chairul SM, Sumarny M, Chairul. 2003. Aktivitas Antioksidan Ekstrak Air DaunTempuyung (Sonchus arvensis L.) secara invitro.Majalah Farmasi Indonesia 14(4): 208-215.

Deshpande SS, DeshpandeUS, and SalunkheDK. 1985. Nutritional and Health Aspects of Food Antioxidants dalam D.L. Madhavi: Food Antioxidant, Technological, Toxilogical and Health Perspectives. Marcel Dekker Inc. Hongkong :361-365

Dixon R, Paiva N.L. 1995. Stress-induced phenylopropanoid metabolism. Plant Cell 7.

Ferreira D, Bekker R. 1996. Oligomeric proanthocyanidins: naturally occurring O-heterocycles. Nat Prod Rep 13: 411-433

Ferreira D, Nel RJ, Bekker R. 1999a. In: Barton DHR, Nakanishi K, Meth-Cohn O, Pinto BM (eds) Comprehensive natural products chemistry. Elsevier, New York

Ferreira DE, Brandt V, Coetzee J, Malan E. 1999b. Condensed tannins. In: Zechmeister L, Herz W, Falk H, Kirby GW, Moore RE (eds) The chemistry of organic natural products. Springer.

Fernando, E.S. 1979. Baccaurea (Euphorbiaceae) in the Philippines. Kalikasan. Philipp. J. Biol. 8:301-312.
Fitri A, Andriani M, Sudarman A, Toharmat T, Yonekura L, Tamura H, Ramli N. 2016. Screening Of Antioxidant Activities And Their Bioavailability Of Tropical Fruit Byproducts From Indonesia. Int $J$ Pharm Pharm Sci. 8(6): 96-100

Goyal, A. K., Mishra, T. and Sen, A. (2013). Antioxidant profiling of Latkan (Baccaurea ramiflora Lour.) wine. Indian Journal of Biotechnology, 12: 137-139.

Hayashi K, Hayashi T, Otsuka H (et al.) 1997. Antiviral activity of 5,6,7-trimethoxyflavone and its potential of the antiherpes activity ofacyclovir. J Antimicrob Chemother 39: $821-824$

Haegens, R. 2000. Taxonomy, phylogeny, and biogeography of Baccaurea, Distichirhops, and Nothobaccaurea (Euphorbiaceae). Journal of Plant Taxonomy and Plant Geography, Supplement 12.

Harborne JB. 1985. Plant phenolics. In: Bella EA, Charlwood BV (eds) Encyclopedia of plant physiology. Springer, Berlin

Harborne JB. 1987. Metode Fitokimia Penuntun Cara Modern Menganalisis Tumbuhan. Bandung: ITB

Harborne JB, Baxter H. 1999. Handbook of natural flavonoids. John Wiley and Sons, Chichester

Harborne JB. 2005. Encyclopedia of Food and Color Additives. CRC Press,Inc. New York.

Harvey A. 2000. Strategies for discovering drugs from previously unexplored natural products. Drug Discov Today 5 (7): 294-300 
Hoet S, Opperdoes F, Brun R, Quetin LJ. 2004.Natural products active against African trypanosomes: a steptowards new drugs. Nat. Prod. Rep.21:353-364.

Hughes DA (2001) Dietary carotenoids and human immunefunction. Nutr 17:823-827 doi:10.1016/ S0899-9007(01)00638-4

Jung CH, Maeder V, Funk F, Frey B, Sticher H, Frosserd E. 2003. Release of phenols from Lupinus albus L. roots exposed to $\mathrm{Cu}$ and their possible role in $\mathrm{Cu}$ detoxification. Plant Soil $252-301$.

Karnjanawipagul P, Nittayanuntawech W, Rojsanga P, Suntornsuk L. 2010. Analysis of $\beta$-Carotene in Carrot by Spectrophotometry. Journal of Pharmaceutical Science 37 (1-2): 8 - 16.

Kumar S, Pandey AK. 2013. Chemistry and Biological Activities of Flavonoids: An Overview. The ScientificWorld Journal. http:// dx.doi.org/10.1155/2013/162750.

Khoo HE, Ismail A, Esa NM, Idris S. 2008. Carotenoid Content of Underutilized Tropical Fruits. Plant Foods Hum Nutr. 63:170-175. DOI 10.1007/s11130-008-0090-z

Lenny S. 2006. Senyawa Flavonoida, Fenilpropanoida, dan Alkaloida. Jurusan Kimia FMIPA USU. Medan

Loureiro, J. Polygamia Dioecia. 1790. Genus XIX. Baccaurea. Fl. Cochinch.: 661-662.

Lim TK. 2012. Edible Medicine and NonMedicine Plants: Volume 4. London New York. Springer.

Lin YF, Yi Z, Zhao YH. 2003.Chinese dai medicine colourful illustrations. Yunnan National Publishing House. Kunming. pp 158-160
Liu, Z., S.B. Carpenter, W.J. Bourgeois, Y. $\mathrm{Yu}$, R.J.Constantin, M.J. Falcon, and J.C. Adam. 1998.Variation in the secondary metabolite camptothecin inrelation to tissue age and season in Camptotheca acuminata. Tree Physiology 18: 265270.

Lumbanraja LB. 2009. Skrining Fitokimia dan uji efek Antiinflamasiekstak etanol daun empuyang (Sonchus arvenis L.) terhadap radangpada tikus. Universitas Sumatera Utara, Medan.

Man JM. 1997. Kimia Makanan. ITB. Bandung.

Macheix JJ, Fleuriet A, Billot J. 1990. Fruit Phenolics. CRC Press, Boca Raton, FL

Mohmod AL, Krishnasamy G, Adenan MI. 2015. Review: Malaysian plants with potential in vitro trypanocidal activity. Annals of Phytomedicine 4(1): 6-16

Maro JP, Alimuddin AH, Harlia. 2015. Aktivitas Antioksidan Hasil Kromatografi Vakum Cair Fraksi Metanol Kulit Batang Ceria (Baccaurea hookeri). JKK.4(4): 35-40

Mikail MA. et al .2015.Baccaurea angulata fruit inhibits lipid peroxidation and inducesthe increase in antioxidant enzyme activities. Eur J Nutr. DOI 10.1007/s00394-0150961-7

Mokhtar SI, Leong PC, Ven LE, Aziz NAA. 2014. Total Phenolic Contents, Antioxidant Activities and Organic Acids Composition of Three Selected Fruit Extracts at Different Maturity Stages. J. Trop. Resour. Sustain. Sci. 2: 40-46 
Morgan JF, Klucas RV, Grayer RJ, Abian J, Becana M. 1997. Complexes of iron with phenolic compounds from soybean nodules and other legume tissues: prooxidant and antioxidant properties. Free Radic. Biol. Med. 22, 861.

Momand L, Zakaria R, Mikail M, Jalal $\mathrm{T}$, Ibrahim $\mathrm{M}$, Wahab RA. 2014. Antimicrobial effect of Baccaurea angulata fruit extracts against human pathogenic microorganisms.Merit Research Journal of Medicine and Medical Sciences 2(10): 229-237.

Muller Argoviensis, J. 1866. Euphorbiaceae.In: A. de Candolle (ed.), Prodromus systematis naturalis regi vegetabilis 15, 2: 456-466.

Nakamura Y, Watanabe S, Miyake N, Kohme H, Osawa T. 2003. Agric food chem.51: 3309-3312

Norazlanshah, Afiq M, Muhammad, Masri M. 2015. Determination of phytochemicals and vitamin content of underutilized Baccaurea angulata fruit. J Pharmacognosy and Phytochemsitry4(4): 192-196

Osakabe N, Sanbongi C, Natsume M, Takazwa T, Gomi S, Osawa T, 1998. Antioxidative Polyphenols Isoloated From, Theobroma cacao. J Agric Food Chem. 46:454-457.

Panjaitan, M.P., 2014, Skrining Fitokimia dan Uji Aktivitas Antioksidan Fraksi Metanol Kulit Batang Ceria (Baccaurea hookeri), Fakultas Matematika dan Ilmu Pengetahuan Alam, Universitas Tanjungpura, Pontianak, (Skripsi).

Perruchon S. 2004. Synthese und struktur-aktivitäts-beziehungen von flavonoiden. [Dissertation]. Technischen Universität Darmstadt, Darmstadt
Porter LJ. 1994. Flavans and proanthocyanidins. In: Harborne, JB (ed). The flavonoids, advances in research since 1986. Chapman and Hall,New York

Rice-Evans C, Miller N, Paganga G. 1996. Structure-Antioxidant Activity Relationships of Flavonoids and Phenolic Acids. Free Radical Biology E Medicine. 20(7): 933-956.

Rijksen, H.D. 1978. A fieldstudy on Sumatran Orang Utans (Pongo pygmaeus abelii Lesson 1827) ecology, behaviour and conservation. Communications Agricultural University Wageningen 78, 2.

Rohyani IS, Aryanti E, Suripto. 2015. Potensi Nilai Gizi Tumbuhan Pangan Lokal Pulau Lombok Sebagai Basis Penguatan Ketahanan Pangan Nasional. Pros Sem Nas Masy Biodiv Indon. 1 (7) : 1698-1701. ISSN: 2407-8050

Salma, I. 1998. BaccaureaLour. In: M.S.M. Sosef, L.T. Hong \& S. Prawirohatmodjo (eds.), Timber trees: lesser known timbers. PROSEA 5, 3: 95-98.

Seal T, Chaudhuri K, Pillai B. 2012. Antioxidant Activity of Some Selected Wild Edible Fruits ofNorth-Eastern Region In India And Effect Of Solvent Extraction System. Global J. Environ. Res. 6 (3): $84-90$

Secco et al. 2012. An overview of recent taxonomic studies on Euphorbiaceae s.l. in Brazil.

Rodriguésia 63(1): 227-242

Singh KK, Singh M, Joshi SC. 2014. Phenolic content and Antioxidant Activity of some Underutilized Wild Edible Fruits of the Sikkim Himalaya. SMU Medical Journal. 2(1). 
Solomon T.E.W., 1980. Organic Chemistry, John Willey and Sons, $2^{\text {th }}$ Ed New York.

Sofowora A. 1982. Medicinal plants and traditional medicine in Africa. Spectrum Books Ltd. Ibadan, Nigeria

Suhaila M, Zahariah H, Norhashimah AH. 1994. Antimicrobial activity of some tropical fruit wastes (Guava, starfruit, banana, papaya, passionfruit, langsat, duku, rambutan and rambai). J. Trop. Agric. Sci., 17(3): 219-227.

Sulaiman SF, Ooi KL. 2014. Antioxidant and $\alpha$-Glucosidase Inhibitory Activities of 40 Tropical Juices from Malaysia and Identification of Phenolics from the Bioactive Fruit Juices of Barringtonia racemosa and Phyllanthus acidus. J. Agric. Food Chem.doi 10.1021

Smith PM. 1976. The chemotaxonomy of plants. Edward Arnold, London.

Smith, A.C. 1978. Prcursor to the flora of Fiji. Allertonia I. 6: 377-389.

Suryani E, Nurmansyah. 2009. Inventarisasi dan karakterisasi tanaman kayu manis seilon (Cinnamomum zeylanicum Blume) di Kebun Percobaan Laing Solok. Buletin Penelitian Rempah dan Obat 20 (2): 100.

Stepp, J.R. and D.E. Moerman. 2001. The importance ofweeds in ethno-pharmacology. Journal of Ethnopharmacology 75: 19-23.

Tapas AR, Sakarkar DM, Kakde RB. 2008. Flavonoids as Nutraceuticals: A Review.Trop J Pharm Res. 7 (3): 1089-1099
Tirtana E, Nora, Warsidah, Afghani J. 2013. Analisa proksimat, uji fitokimia dan aktivitas antioksidan pada buah tampoi (Baccaureamacrocarpa). Jurnal Kimia Khatulistiwa 2 (1): 42-45.

Uji, T. 1991. Baccaurea Lour. In: E.W.M. Verheij \& R.E.Coronel, Edible fruits and nuts. Bogor. PROSEA 2: 98-100, 319-320.

Ullah MO, Urmi KF, Howlader MDA, Hossain MDK, Ahmed MT, Hamid K. 2012. Hypoglycemic, Hypolippidemic And Antioxidant Effects Of Leaves MethanolicExtract Of Baccaurea Ramiflora.Int J Pharm Pharm Sci.4 (3): 266-269.

Usha T, Middha SK, Bhattacharya M, Lokesh P, Goyal AK. 2014. Rosmarinic Acid, a New Polyphenol from Baccaurea ramiflora Lour. Leaf: A Probable Compound for Its Anti-Inflammatory Activity. Antioxidants 3: 830-842

Van Valkenburg, J.L.C.H. 1997. NonTimber forest products of East Kalimantan. Potentials for sustainable forest use. Tropenbos Series 16.

Voon, B.H.; Kueh, H.S. 1999. The nutritional value of indigenous fruits and vegetables in Sarawak. Asia Pac. J. Clin. Nutr., 8, 24-31.

Wong KC, Wong SW, Siew SS, Tie DY (1994) Volatile constituents of the fruits of Lansium domesticum (duku and langsat) and Baccaurea motleyana (Muell. Arg.) Muell. Arg. (rambai). Flav Fragr J 9(6):319-324 
Wetwitayaklung P, Charoenteeraboon J, Limmatvapirat C, Phaechamud T. 2012.Antioxidant Activities of Some Thai and Exotic Fruits Cultivated in Thailand. Research Journal of Pharmaceutical, Biological and Chemical Sciences. 3(1): 12

Wulansari D, Chairul. 2011. Penapisan aktivitas antioksidan dan beberapa tumbuhan Obat indonesia menggunakan radikal 2,2-diphenyl-1 Picrylhydrazyl (dpph). Majalah Obat Tradisional, 16(1): 22 - 25,

Whitmore,T.C. 1973. Baccaurea. Tree Fl. Malaya 2: 63-67.Zietkiewicz E, Rafalski A,
Yan X, Chuda Y, Suzuki M, Nagata T. 1999. Fucoxanthin as The Major Antioxidant in Hijikia fusiformis, a Common Edible Seaweed. Biosci. Biotechnol. Biochem. 63:605-607.

Yang, X.W.; Wang, J.S.; Ma, Y.L.; Xiao, H.T.; Zuo, Y.Q.; Lin, H.; He, H.P.; Li, L.; Hao, X.J. 2007. Bioactive Phenols from the Leaves of Baccaurea ramiflora. Planta Med. 73:1415-1417.

Zeb, Alam, Mehmood, Sultan, 2004. Caotenoid Contents from VariousSources and Their Potential HelthApplications. Pakistan Journal ofNutrition. 3 (3): 199-204. 